\title{
Analisis karakteristik pengguna jalan di Kota Padang
}

\author{
Imelda M. Nur ${ }^{1}$, Gusri Yaldi ${ }^{2}$, Apwiddhal ${ }^{3}$, Syaiful Amri ${ }^{4}$, Momon ${ }^{5}$ \\ 1 Jurusan Administrasi Niaga, Politeknik Negeri Padang \\ ${ }^{2}$ Jurusan Teknik Sipil, Politeknik Negeri Padang \\ ${ }^{3}$ Badan Penelitian dan Pembangunan Provinsi Sumatera Barat \\ Email : qusri.yaldi@pnp.ac.id
}

\begin{abstract}
Abstrak- Pemakaian bahan bakar minyak (BBM) cenderung meningkat selaras dengan pertambahan jumlah kendaraan bermotor di Indonesia. Pada level nasional, BBM adalah sumber energi utama dimana mayoritasnya dikonsumsi oleh moda transportasi darat seperti mobil pribadi/kendaraan penumpang dan angkutan barang. Sedangkan angkutan umum hanya mengkonsumsi 9\% saja. Terdapat peluang untuk mengurangi konsumsi pemakaian BBM oleh sektor transportasi khususnya transportasi darat, melalui peningkatan market share penggunaan angkutan umum dengan mengajak pengguna jalan untuk beralih dari pemakaian mobil pribadi ke angkutan umum/BRT seperti yang diharapkan oleh pemerintah. Untuk itu terlebih dahulu perlu di analisis karakter pengguna jalan eksisting agar dapat di rancang skema angkutan umum yang dapat memenuhi kebutuhan dan kepuasan pengguna jalan yang merupakan tujuan dari penelitian ini. Harapannya adalah luaran yang dihasilkan dapat digunakan oleh stakeholder terkait sebagai pertimbangan dalam merancang angkutan umum yang dapat memberikan manfaat dan keuntungan maksimum bagi pengguna jalan.
\end{abstract}

Kata kunci: Karakteristik pengguna jalan, BRT, Demand

\section{PENDAHULUAN}

\subsection{Latar Belakang}

Sektor transportasi di Indonesia merupakan konsumen bahan bakar minyak (BBM) terbesar, diikuti oleh sektor rumah tangga/servis, dan industri (BPPN, 2006). Lebih dari $50 \%$ pemakaian BBM nasional digunakan oleh sektor transportasi dan $88 \%$ nya adalah konsumsi sub sektor transportasi darat. Jika lebih di rinci lagi, maka mobil pribadi merupakan konsumen terbesar dengan persentase $34 \%$. Karena itu wajar jika pemerintah berusaha untuk mengurangi subsidi harga BBM atau membatasi pemakaian BBM bersubsidi. Di samping untuk mengurangi beban anggaran, adalah juga untuk ikut andil dalam mengatasi krisis energi dunia dalam bentuk mengurangi pemakaian BBM.

Namun, dari perspektif transportasi terdapat alternatif lain dalam mengurangi pemakaian BBM yaitu melalui peningkatan market share pengguna angkutan umum sebagai moda transportasi yang lebih sustainable dan mengurangi jumlah perjalanan dengan menggunakan moda mobil pribadi. Apalagi angkutan umum hanya mengkonsumsi sembilan persen saja konsumsi BBM nasional
(BPPN, 2006). Dengan skema ini, tidak hanya konsumsi BBM yang dapat diturunkan, tapi juga dapat mengurangi jumlah kendaraan di jalan raya, apalagi terdapat gap yang besar antara pertumbuhan jalan raya dan pertumbuhan jumlah kendaraan bermotor setiap tahunnya. Hal terakhir ini adalah disinyalir salah satu penyebab tingginya angka kecelakaan di jalan raya (Soehodho, 2007).

Untuk meningkatkan market share dari penggunaan angkutan umum melalui peralihan moda dari mobil pribadi ke angkutan umum (mode shift), maka perlu diketahui terlebih dahulu karakteristik pengguna jalan seperti socio-economic dan perjalanannya agar fasilitas angkutan umum yang disediakan dapat memberikan manfaat maksimum kepada calon pengguna. Penelitian ini hadir dengan maksud untuk mengetahui profil pengguna jalan eksisting untuk dapat digunakan pada perancangan skema angkutan umum yang memberikan kepuasan maksimum bagi masyarakat dan mampu mendorong mereka untuk beralih dari kendaraan pribadi ke angkutan umum. 


\section{PENGUMPULAN DATA}

Pemerintah kota Padang bermaksud untuk mengembangkan angkutan Bus Rapid Transit (BRT) (Dishub, 2010). Terdapat lima korior pelayanan BRT seperti terlihat pada Gambar 1.

Koridor 1 sudah beroperasi sejak Februari 2014. Agar manfaat penelitian ini lebih efektif maka difokuskan pada Koridor 3 (IndarungPusat Kota Padang). Telah dilakukan survey karaktersitik pengguna jalan, seperti kepemilikan kendaraan bermotor, maksud perjalanan dan kendaraan yang digunakan saat ini. Survey ini dilakukan untuk hari kerja dan juga Sabtu dan Minggu dengan total responden 547 orang (termasuk pilot survey sebanyak 50 orang responden).

\section{KARAKTERISTIK RESPONDEN}

\subsection{Berdasarkan ukuran keluarga, jenis kelamin dan usia}

Gambar 2 dan 3 memperlihatkan jumlah responden berdasarkan ukuran keluarga, jenis kelamin dan usia. Berdasarkan ukuran keluarganya, maka responden terdistribusi seperti terlihat pada Gambar 2. Persentase terbesar adalah keluarga dengan jumlah anggota 6 orang, diikuti dengan ukuran keluarga 5, 4, dan 3 orang. Ukuran keluarga terbesar adalah 12 orang, dengan persentase sebesar $2 \%$. Terdapat gap yang relatif besar antara responden laki-laki dan perempuan yaitu $59 \%$ responden adalah laki-laki sedangkan perempuan adalah $41 \% 4$. Jumlah responden terbesar adalah pada usia rentang 20-25 tahun diikuti oleh responden dengan usia pada rentang 25-30 tahun. Terlihat bahwa mayoritas responden adalah pada usia produktif.

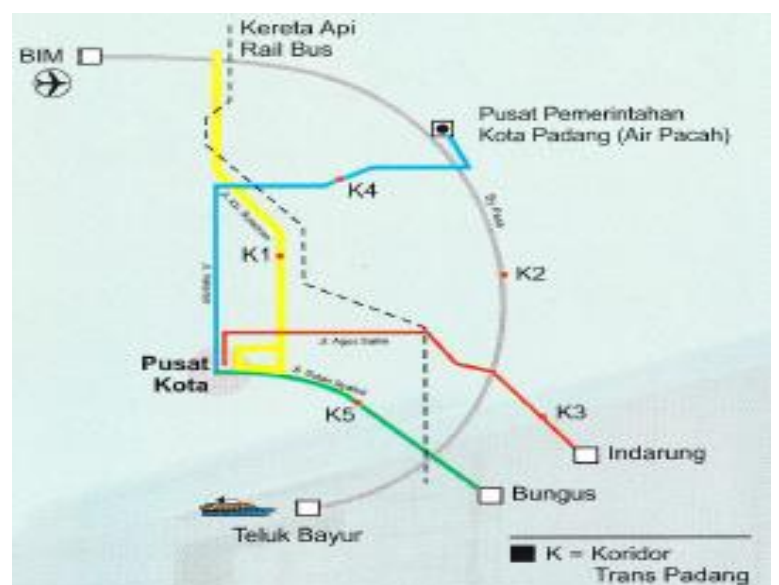

Gambar 1 Rencana pengembangan BRT (Yaldi et al., 2014)

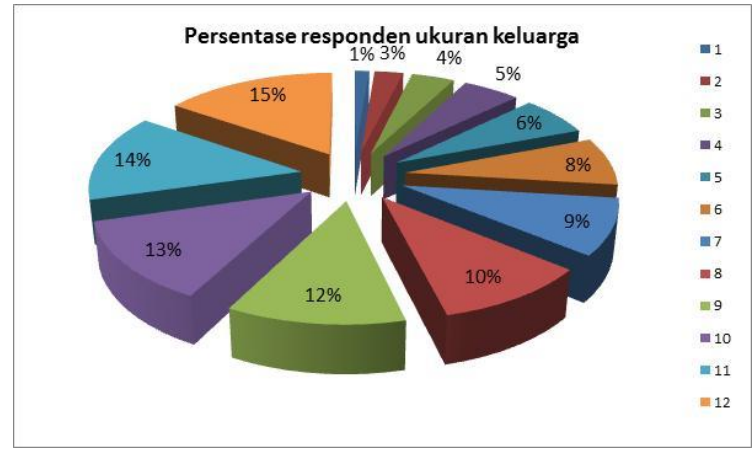

\section{Gambar 2 Persentase responden berdasarkan ukuran keluarga}

\subsection{Berdasarkan pendidikan dan pekerjaan}

Dari segi pendidikannya, maka mayoritas responden (70\%) dengan pendidikan SD, SMP, dan SMA. Responden dengan latar belakang pendidikan perguruan tinggi seperti Diploma 3 (D3) dan Strata 1 (S1) adalah 30\% seperti terlihat pada Gambar 5. Jika diklasifikasikan menurut pekerjaannya, 50\% responden adalah bekerja pada sektor swasta, diikuti oleh mahasiswa dan pelajar dengan persentase $20 \%$ dan $13 \%$ berturut-turut. Responden dengan pekerjaan pegawai negeri sipil adalah 8\% seperti terlihat pada Gambar 6 . Distribusi responden seperti ini akan berdampak kepada data lainnya seperti pendapatan per bulan karena responden yang berstatus mahasiswa dan pelajar tentunya belum memiliki penghasilan.

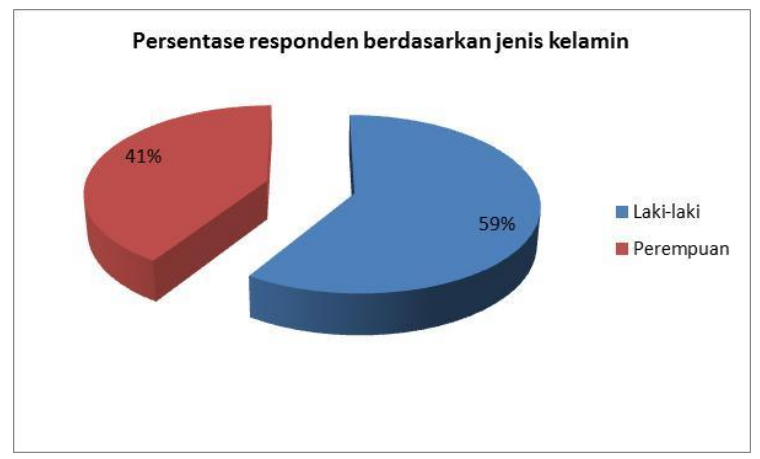

\footnotetext{
Gambar 3 Persentase responden berdasarkan jenis kelamin
} 


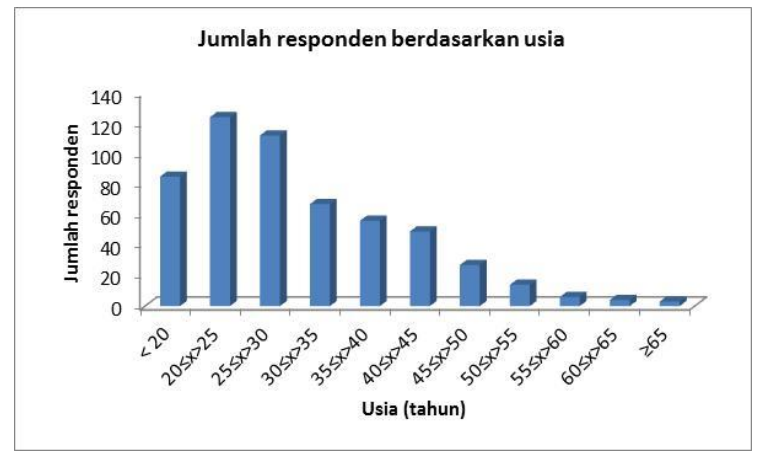

\section{Gambar 4 Profil responden berdasarkan} usia

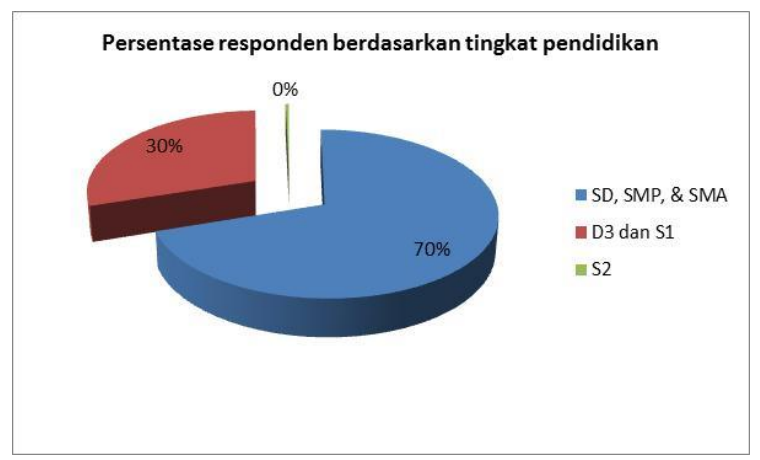

\section{Gambar 5 Persentase responden berdasarkan latar belakang pendidikan}

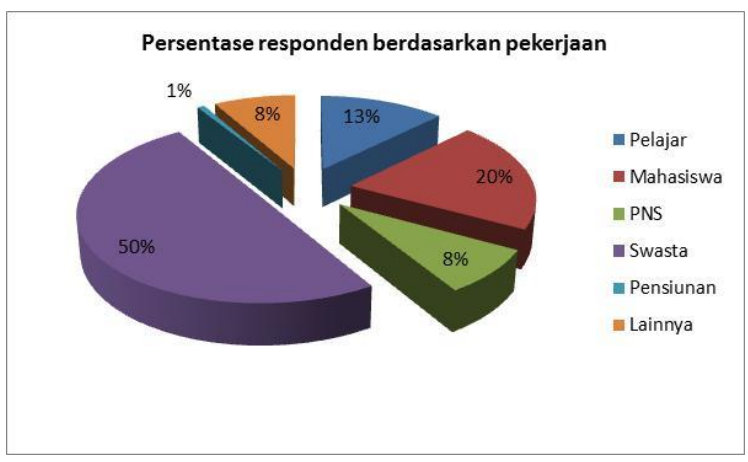

\section{Gambar 6 Persentase responden berdasarkan pekerjaan}

\subsection{Berdasarkan pendapatan kepemilikan kendaraan bermotor}

dan

Gambar 7 memperlihatkan jumlah responden berdasarkan informasi apakah memiliki pendapatan atau tidak. Dari survey diperoleh informasi bahwa $62 \%$ responden memiliki penghasilan rata-rata Rp. 2.2 juta perbulan dengan penghasilan terendah adalah kurang dari Rp. 1 jt dan terbesar adalah Rp. 15 juta. Terdapat gap yang relatif besar antara penghasilan terbesar dan terkecil. Sementara itu, $28 \%$ responden tidak memiliki penghasilan dan persentase ini terkait dengan persentase responden yang masih berstatus mahasiswa dan pelajar dimana persentasenya mencapai $33 \%$.

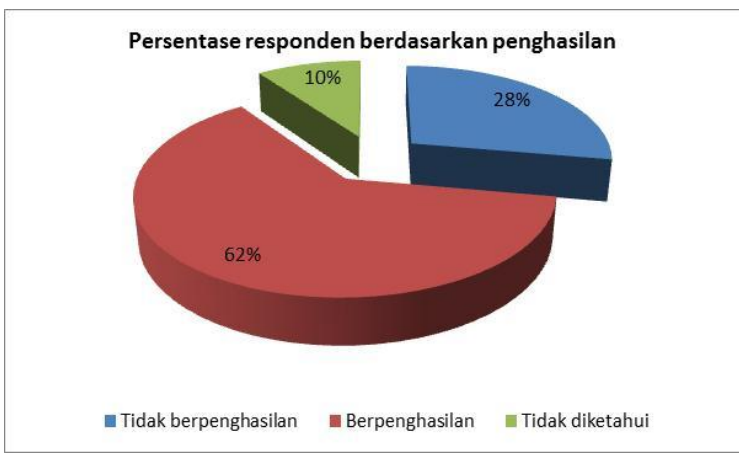

\section{Gambar 7 Persentase responden informasi penghasilan}

Untuk kepemilikan kendaraan bermotor, lebih dari seperempat responden memiliki mobil dan mayoritas adalah 1 unit. Untuk sepeda motor, hampir seluruh responden memiliki sepeda motor. Sedangkan persentase responden dengan jumlah sepeda motor lebih dari 1 adalah hampir $40 \%$ dari total responden (lihat Gambar 8 dan 9 untuk lebih detailnya). Data ini mengindikasikan bahwa adanya kecenderungan dan ketergantungan masyarakat kepada sepeda motor. Di samping harga yang relatif terjangkau dan kemudahan untuk mendapatkannya melalui skema kredit, menyebabkan sepeda motor hampir dimiliki oleh seluruh masyrakat. Apalagi responden dengan status mahasiswa dan pelajar, lebih dari $90 \%$ nya adalah menggunakan sepeda motor.

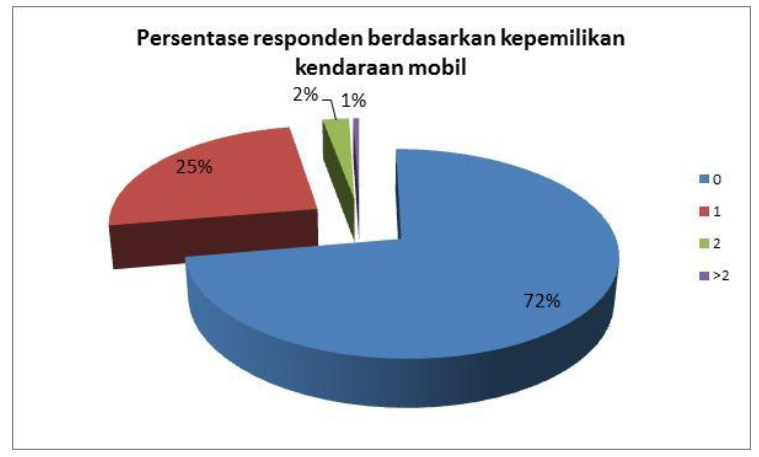

Gambar 8 Persentase responden informasi penghasilan 


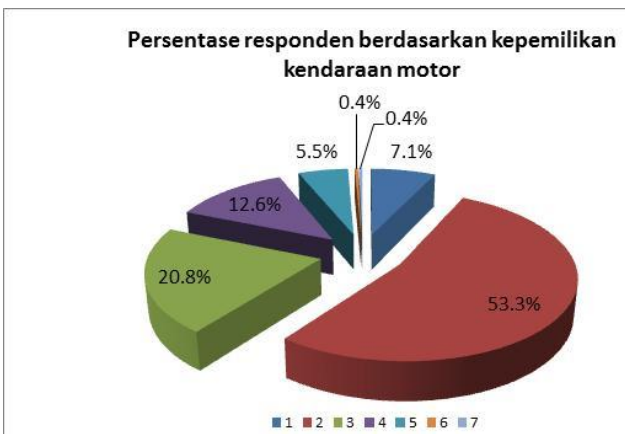

Gambar 9 Persentase responden informasi penghasilan

\section{KARAKTERISTIK RESPONDEN}

\subsection{Berdasarkan asal perjalanan}

Berdasarkan asal perjalanannya, persentase terbesar adalah responden yang memulai perjalanannya dari rumah diikuti dari kantor dan sekolah dengan persentase $74 \%, 13 \%$, dan $6 \%$ berturut-turut. Persentase ini adalah terkait dengan waktu pelaksanaan survey yang umumnya dilakukan pada pagi hari sehingga hasilnya adalah mayoritas responden memulai perjalanannya dari rumah seperti terlihat pada Gambar 10.

\subsection{Berdasarkan waktu tempuh}

Rata-rata waktu tempuh perjalanan responden adalah 19.4 menit. Hampir separuh responden (49\%) melakukan perjalanan dengan waktu tempuh kurang dari 15 menit (lihat Gambar 11). Berikutnya adalah perjalanan responden dengan waktu tempuh antara 16-20 menit sebanyak $21 \%$ persen. Apabila digabung maka terdapat $70 \%$ responden yang melakukan perjalanan dengan waktu tempuh maksimum 20.

Dengan waktu tempuh tersebut, apabila menggunakan kendaraan pribadi seperti sepeda motor (hasil survey mengindikasikan bahwa lebih dari 90 persen masyarakat memiliki sepeda motor-hampir $40 \%$ memiliki lebih dari 1 sepeda motor)-adalah untuk perjalanan dengan jarak maksimum $\pm 10 \mathrm{Km}$.

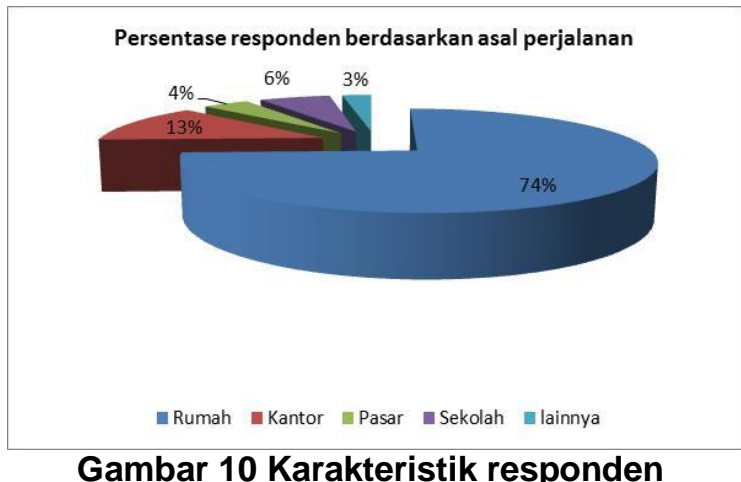

\section{Gambar 10 Karakteristik responden berdasarkan asal perjalanan}

\subsection{Berdasarkan biaya perjalanan}

Biaya perjalanan yang dikeluarkan untuk satu kali perjalanan adalah rata-rata Rp.5360. Dari Gambar 12 dapat diketahui bahwa 33\% responden melakukan perjalanan dengan biaya antara Rp.2000-3000. Persentase terbesar kedua adalah responden dengan biaya perjalanan Rp.6000-7000 dengan persentase $22.4 \%$.

Dapat diprediksi bahwa persentase responden dengan biaya perjalanan terbesar pada rentang Rp.2000-3000 adalah berkaitan dengan beberapa faktor seperti dengan moda yang digunakan yaitu sepeda motor. Sebanyak $72 \%$ responden dengan biaya perjalanan Rp.2000-3000 adalah pengguna sepeda motor.

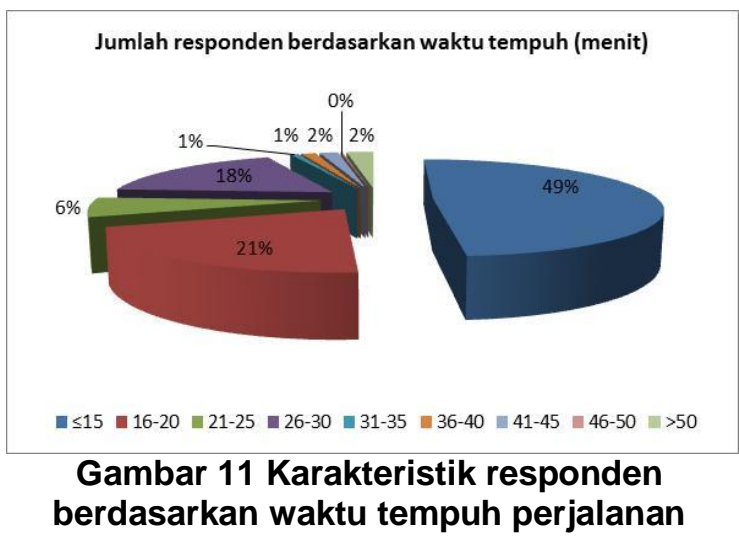

\subsection{Berdasarkan maksud perjalanan perjalanan}

Berdasarkan maksud perjalanannya, persentase terbesar adalah untuk maksud perjalanan bekerja, sekolah/kuliah, dan belanja dengan persentase $50 \%$, 29\%, dan $16 \%$ berturut-turut. Terlihat bahwa perjalanan dengan maksud bekerja adalah mendominasi seperti terlihat pada Gambar 13. 


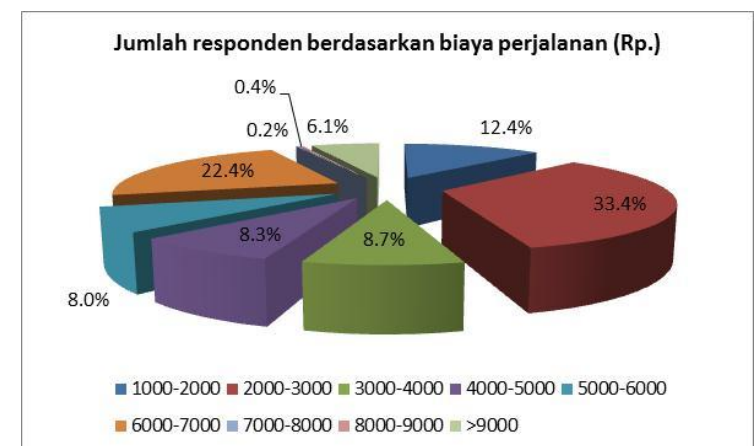

\section{Gambar 12 Karakteristik responden berdasarkan biaya perjalanan}

\subsection{Berdasarkan moda transportasi utama}

Sebelumnya sudah dijelaskan bahwa hampir seluruh responden memiliki sepeda motor, bahkan hampir $40 \%$ persen responden memiliki lebih dari dua sepeda motor. Yang memiliki kendaraan bermotor roda empat hanya $38 \%$ responden. Statistik ini akan menentukan jumlah perjalanan berdasarkan moda utama yang digunakan seperti terlihat pada Gambar 14.

Terdapat enam moda yang terdapat dalam formulir questionnaire, yaitu (1) Mobil, (2) Angkot, (3) Taksi, (4) Trans Padang, (5) Sepeda motor, dan (6) Lainnya. Dari enam pilihan moda tersebut, persentase tertinggi adalah sepeda motor diikuti oleh angkot dan mobil dengan persentase masing-masing adalah $75 \%$, 17\%, dan 7\% berturut-turut. Terlihat bahwa sepeda motor sangat mendominasi dan berkorelasi dengan kepemilikan sepeda motor. Jika di gabung dengan moda mobil, maka persentase responden yang melakukan perjalanan dengan kendaraan pribadi (sepeda motor dan mobil) adalah mencapai $82 \%$.

Persentase responden berdasarkan maksud perjalanan

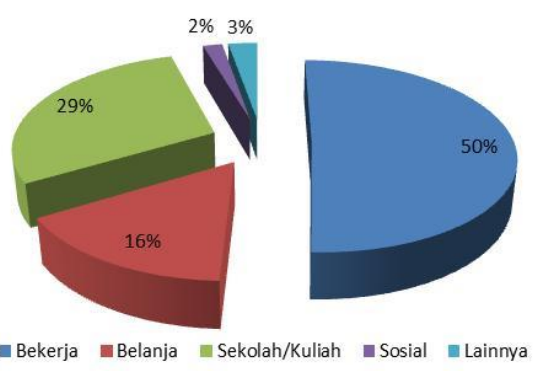

Gambar 13 Karakteristik responden berdasarkan maksud perjalanan

\subsection{Berdasarkan faktor pemilihan moda}

Dalam memilih moda yang akan digunakan untuk melakukan perjalanan, responden melihat faktor waktu tempuh perjalanan sebagai faktor utama yang sangat dominan, diikuti oleh biaya perjalanan, aksesibilitas, dan keselamatan dan kenyaman. Terdapat gap yang besar antara faktor pertama (waktur tempuh) dengan faktor-faktor yang lainnya dan diduga penyebab dari tingginya angka kepemilikan sepeda motor. Yang menarik adalah pada faktor ke-7, "angkutan umum tidak ada". Ini mengindikasikan angkutan umum sudah dapat memenuhi demand dari pengguna jalan, atau pengguna jalan tidak terlalu peduli dengan faktor ini. Lebih detail terkait persentase faktor dalam pemilihan moda transportasi dapat di lihat apda Gambar 15.

Selanjutnya Gambar 16 memberikan ilustrasi perhatian responden terhadap krisis energi, polusi udara, macet, harga BBM dan kecelakaan lalu lintas dalam memilih moda dibandingkan dengan faktor waktu tempuh dan biaya. Hasilnya adalah faktor waktu tempuh dan biaya perjalanan masih menjadi faktor utama dibanding isu krisis energi, polusi udara, macet, harga BBM dan kecelakaan lalulintas.

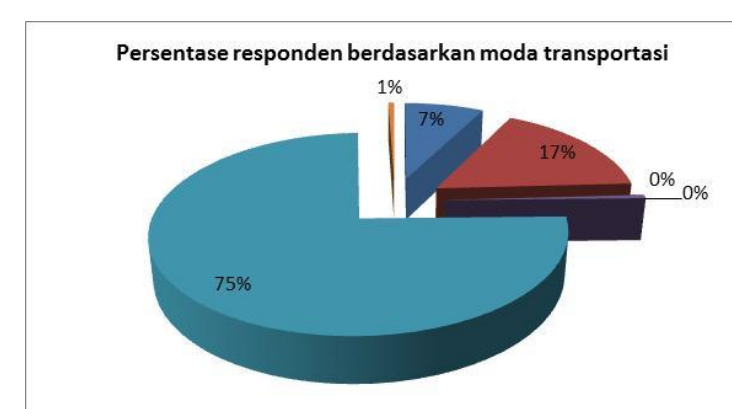

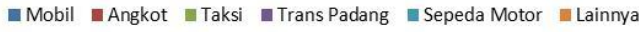

\section{Gambar 14 Karakteristik responden berdasarkan moda utama}

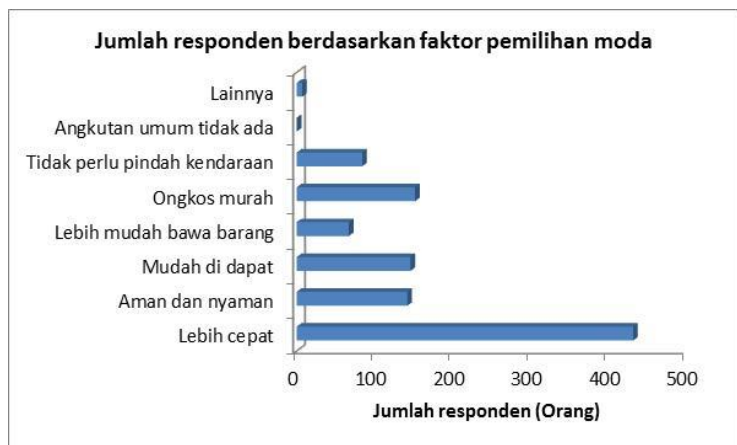

Gambar 15 Karakteristik responden berdasarkan faktor pemilihan moda 


\subsection{Berdasarkan waktu tunggu dan frekuensi ganti moda}

Dikarenakan mayoritas responden adalah memiliki menggunakan sepeda motor dan mobil dengan persentase mencapai $82 \%$, maka mayoritas waktu tunggu moda adalah nol menit seperti terlihat pada Gambar 17 dan 18. Terdapat indikasi responden mengharapkan moda transportasi dengan waktu tunggu dan tempuh yang singkat dan cenderung untuk melakukan perjalanan dengan kendaraan pribadi. Pemerintah dan operator angkutan umum perlu mengantisipasi harapan responden terkait dengan faktor waktu seperti waktu tempuh dan waktu tunggu jika ingin meningkatkan market share angkutan umum yang dikelolanya sehingga dampak negatif dari kendaraan bermotor seperti kecelakaan lalulintas, macet, polusi, dan konsumsi energi dapat di reduksi.

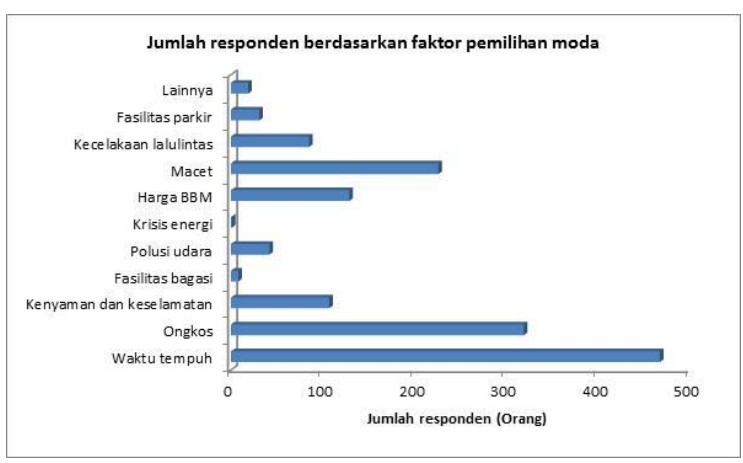

\section{Gambar 16 Karakteristik responden} berdasarkan faktor pemilihan moda

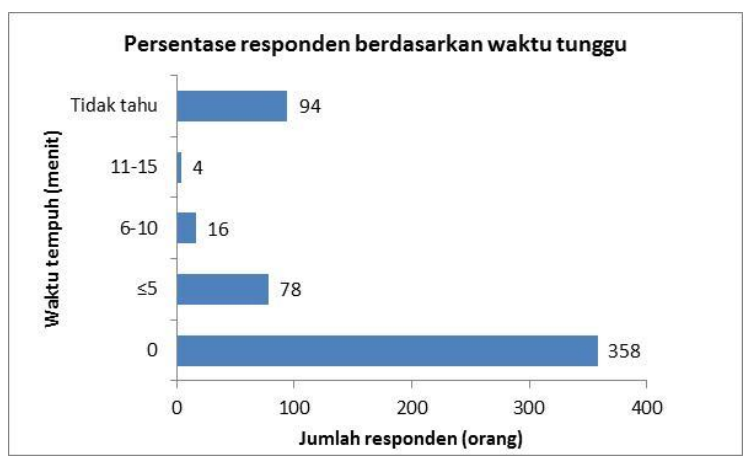

\section{Gambar 17 Karakteristik responden berdasarkan waktu tempuh}

\subsection{Berdasarkan informasi layanan Trans Padang}

Walaupun daerah kajian belum termasuk dalam koridor pelayanan BRT Trans Padang yang sudah beroperasi, namun informasi terkait layanan BRT ini juga ditanyakan kepada responden sehingga efektifitas dari sosialisasi layanan BRT di kota Padang untuk daerah yang belum terlayani dapat diketahui juga melalui kajian ini. Dari Gambar 19 terlihat bahwa $60 \%$ responden mengetahui layanan Trans Padang sedangkan $36 \%$ pernah mendengar informasi ini dan hanya $4 \%$ responden yang tidak mengetahuinya.

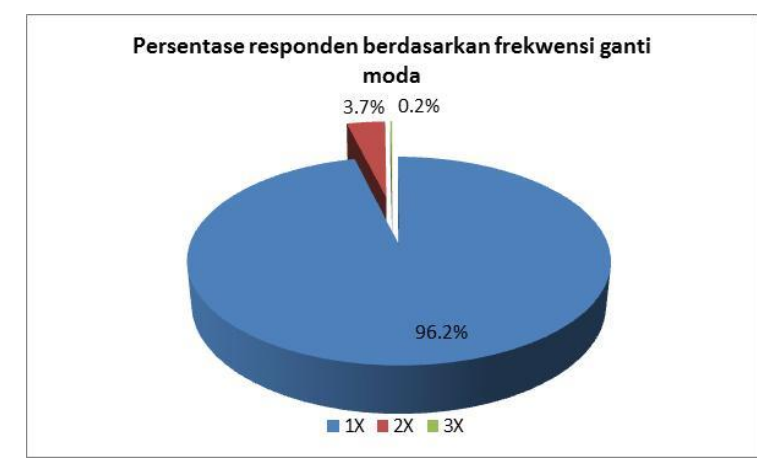

\section{Gambar 18 Karakteristik responden berdasarkan frekuensi ganti moda}

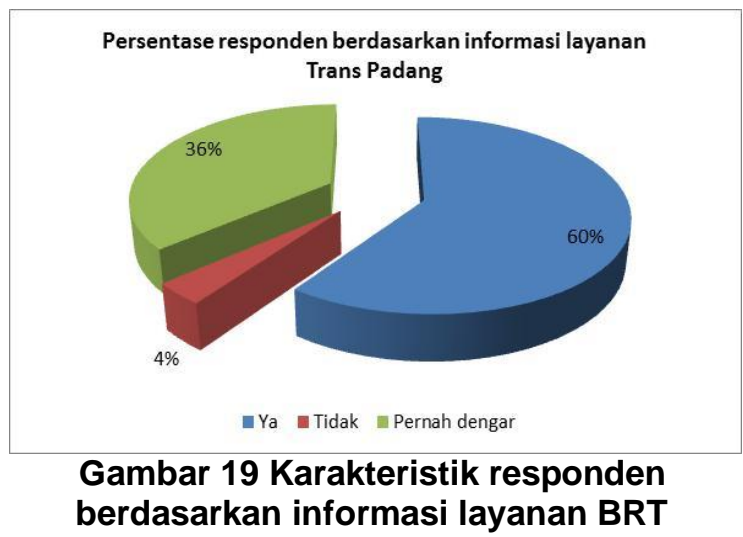

Apabila terdapat layanan BRT seperti Trans Padang pada koridor ini, maka responden akan memilih untuk menggunakan BRT dengan faktor keselamatan dan kenyamanan moda BRT sebagai faktor utama. Faktor berikutnya adalah tarif atau ongkos perjalanan. Tetapi, alasan utama responden untuk tidak menggunakan BRT adalah waktu tunggu yang lama serta terlalu sering berhenti diikuti oleh waktu tempuh lama. Tampaknya responden terpengaruh oleh pengalaman dari menggunakan angkutan umum seperti bus kota yang sempat beroperasi hingga tahun 2012. Kualitas pelayanan bus kota yang dianggap kurang baik pada masa lampau dikhawatirkan juga akan terjadi pada layanan BRT yang akan ditawarkan kepada responden. Untuk lebih detailnya dapat di lihat Gambar 20 dan 21. 
Jumlah responden berdasarkan faktor menggunakan Trans Padang
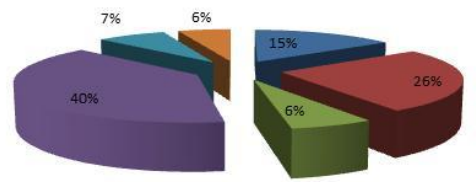

- Tidak punya kendaraan priba - Dekat dengan r

- Ongkos le bih murah = Lainnya

Gambar 20 Karakteristik responden berdasarkan faktor menggunakan BRT

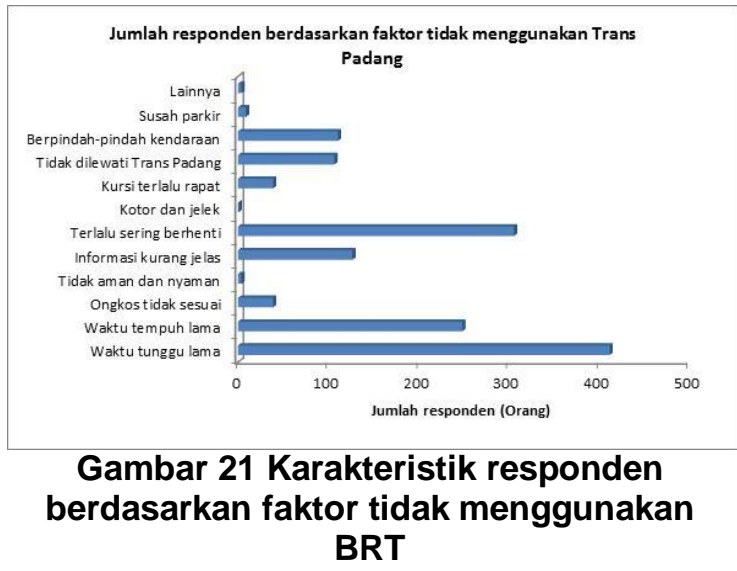

\subsection{Berdasarkan kepulangan}

keberangkatan

dan

Dalam survey ini juga ditanyakan kepada responden jam berapa responden memulai aktifitas seperti jam keberangkatan dan jam kepulangan. Hasilnya dapat di lihat pada Gambar 22 dan 23. Responden berangkat dari lokasi memulai perjalanan yang mayoritas dari rumah yang terbesar adalah antara pukul 06.30 sampai dengan 07.00 pagi dan diikuti setelah pukul 07.30. Tapi, dilihat dari distribusinya maka perbedaan persentasenya tidak mencolok-kecuali yang berangkat awal seperti sebelum pukul 06.30 dengan persentase $11 \%$.

Sementara itu, pada saat pulang polanya hampir sama. Jam kepulangan adalah cenderung merata dengan persentase tertinggi setelah jam 4 sore diikuti sebelum jam 3 sore. Informasi ini dapat digunakan dalam perencanaan jadwal operasional angkutan umum seperti BRT dan dapat diperkirakan demand puncak dan kebutuhan terhadap terhadap layanan transportasi.
Berikutnya adalah mayoritas responden cenderung untuk melakukan perjalanan sendirian, baik pada saat memulai perjalanan maupun pada saat pulang seperti terlihat pada Gambar 24 dan 25. Dengan demikian dapat diestimasi occupation rate dari moda yang digunakan adalah mayoritas 1 orang per kendaraan dan kendaraan tersebut adalah mayoritas kendaraan pribadi.

Jika trend ini terus berlangsung, maka diprediksi jalan raya akan dipenuhi oleh kendaraan pribadi, terumatama kendaraan roda dua. Kondisi seperti ini berpotensi untuk untuk meningkatan kemacetan, kecelakaan lalulintas, polusi, konsumsi energi dan dampak negatif lainnya.

Persentase responden berdasarkan jam keberangkatan

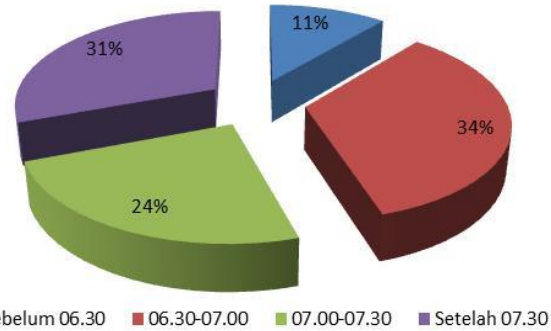

Gambar 22 Karakteristik responden berdasarkan faktor jam keberangkatan

\subsection{Berdasarkan captive dan choice user}

Untuk mengetahui potensi demand dari angkutan umum seperti BRT, maka ditanyakan kepada responden apakah memiliki moda transportasi alternatif selain dari moda yang biasa digunakan dan jawabannya dapat di lihat pada Gambar 26. Terlihat bahwa 81\% responden menyatakan tidak memiliki moda pilihan lain selain yang biasa digunakan (captive user) dan hanya 19\% menyatakan memiliki moda pilihan lain (choice user). Untuk responden choice user, jumlah responden berdasarkan moda eksistingnya dapat di lihat pada Gambar 27.

Statistik ini memberi indikasi bahwa responden cenderung nyaman dengan moda yang biasa digunakan yang merupakan kendaraan pribadi dengan mayoritas sepeda motor. Atau bisa juga responden merasa skeptis dengan kualitas layanan angkutan umum seperti BRT Trans Padang. Walaupun sebagian besar 
responden sudah mengetahui layanan BRT Trans Padang pada koridor lain melalui sosialisasi pemerintah dan operator, mereka cenderung pesimis layanan angkutan umum yang sesuai dengan kriteria yang diinginkan dapat terwujut.

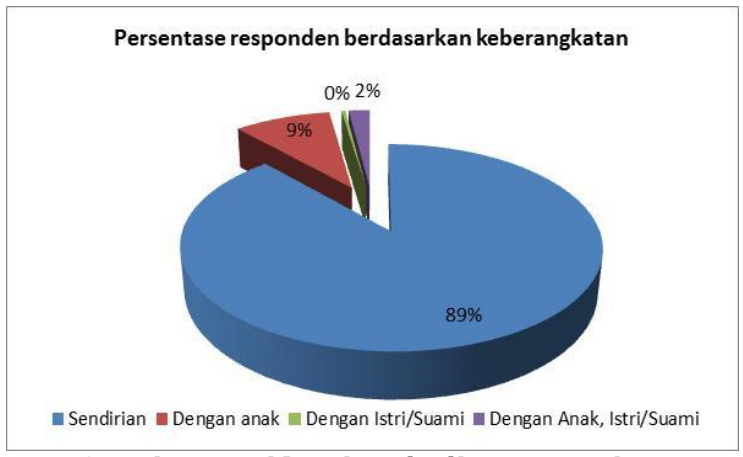

Gambar 23 Karakteristik responden berdasarkan keberangkatan

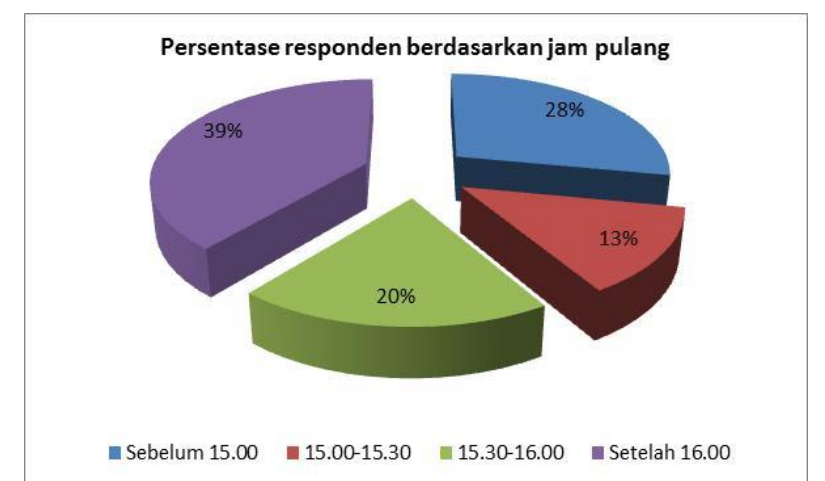

Gambar 24 Karakteristik responden berdasarkan jam kepulangan

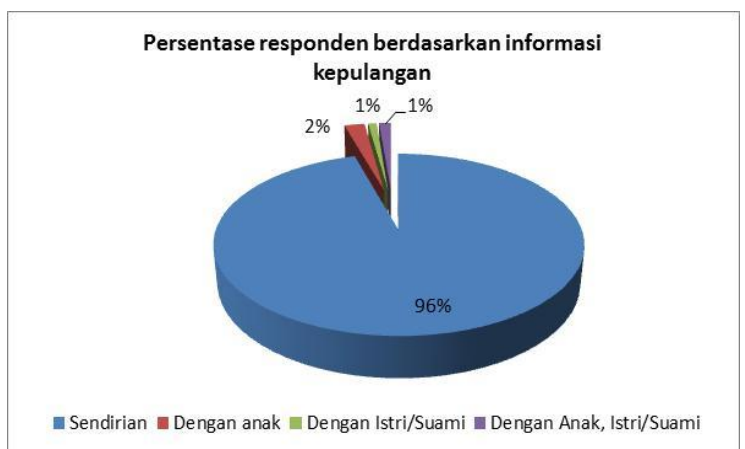

Gambar 25 Karakteristik responden berdasarkan kepulangan

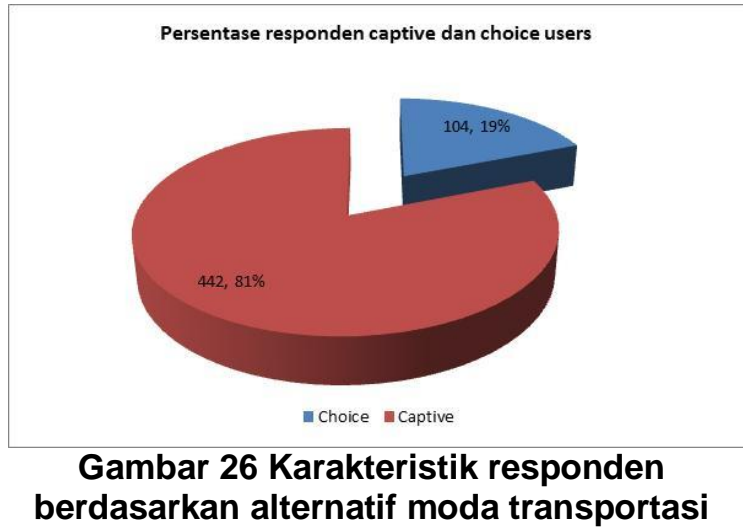

\section{POTENSI DEMAND ANGKUTAN UMUM}

Pada Gambar 26 dan 27 terlihat $19 \%$ responden yang memiliki moda alternatif selain dari moda yang biaya digunakan. Untuk captive user, apabila di lihat moda utamanyamaka terdapat $10.6 \%$ responden yang memilih untuk tetap menggunakan angkutan umum yang ada, dengan rincian sebagai berikut:

- Responden yang memilih untuk tetap menggunakan angkot sebanyak 55 orang

- Responden yang memilih untuk tetap menggunakan Trans Padang sebanyak 3 orang

Apabila digabung dengan choice user, maka jumlah responden yang berpotensi untuk menggunakan kendaraan umum adalah sebanyak 94 orang (36 orang dari choie user) atau sekitar $17.1 \%$. Persentase ini merepresentasikan potensi demand minimum dari angkutan umum seperti BRT. Tetapi perlu usaha untuk meyakinkan responden menggunan angkutan umum sehingga peluang ini dapat direalisasikan. Potensi ini boleh jadi bertambah, karena karakteristik BRT virtual belum dijelaskan kepada responden.

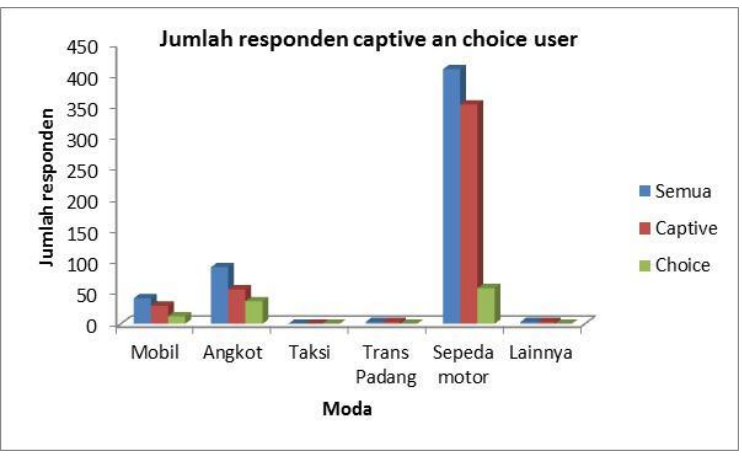

Gambar 27 Jumlah responden captive dan choice user berdasarkan moda 


\section{KESIMPULAN}

Dari hasil analisis dapat di ambil kesimpulan utama sebagai berikut:

- Lebih dari 90\% memiliki sepeda motor dan hampir $40 \%$ diantaranya memiliki sepeda motor lebih dari 1 unit. Hanya 28\% responden yang memiiki kendaraan mobil. Statistik ini memberikan gambaran bahwa responden cenderung merasa nyaman untuk menggunakan kendaraan pribadi dalam melakukan kegiatan sehari-harinya

- Sekitar $74 \%$ responden memulai perjalanannya dari rumah dengan maksud perjalanan bekerja sebesar $50 \%$ diikuti dengan maksud perjalanan sekolah dan kuliah sebesar 29\%. Konsekwensinya adalah responden membutuhkan sarana transportasi yang reliable dan untuk kondisi sekarang ini faktor tersebut dapat dipenuhi oleh kendaraan pribadi

- Waktu tempuh rata-rata adalah 19.4 menit dan $70 \%$ responden melakukan perjalanan dengan waktu tempuh kurang dari 20 menit

- Lebih dari $45 \%$ responden melakukan perjalanan dengan biaya kurang dari Rp. 3000 , atau biaya transportasi bulanan sekitar $8 \%$ dari gaji per bulan

- Moda transportasi utama yang digunakan responden untuk melakukan perjalanan adalah mayoritas sepeda motor, diikuti oleh angkot, dan mobil pribadi dengan persentase $75 \%, 17 \%$, dan $7 \%$ berturutturut. Apabila digabung, maka yang menggunakan kendaraan pribadi adalah $82 \%$

- Waktu tempuh (menghindari macet) dan biaya merupakan dua faktor utama yang jadi pertimbangan responden dalam memilih moda, diikuti oleh faktor aksesibilitas, dan kenyaman dan keselamatan. Berdasarkan data survey, faktor-faktor tersebut diperoleh responden dari kendaraan pribadi yang mereka gunakan

- Sementara itu, faktor krisis nergi, polusi, kecelakaan lalulintas dan konsumsi BBM kurang dipertimbangkan oleh responden dalam memilih moda transportasi. Faktorfaktor ini adalah variabel yang diharapkan dapat diantisipaasi oleh angkutan umum seperti BRT.

- Terkait dengan layanan bus kota BRT, 96\% responden sudah mengetahuinya dan hanya $4 \%$ yang belum mengetahui. Statistik mengindikasikan program sosialisasi layanan BRT oleh pemerinta daerah kota Padang adalah berjalan dengan baik.
- Responden cenderung akan menggunakan angkutan umum seperti BRT dengan faktor kenyamanan dan keselamatan pada prioritas utama, diikuti oleh ongkos, dan karena tidak memiliki kendaraan pribadi. Sementara itu, data statistik dari survey ini terdapat sekitar $82 \%$ responden yang memiliki kendaraan pribadi. Pemerintah perlu mempertimbangkan untuk mengurangi jumlah kepemilikan kendaraan pribadi ini.

- Responden cenderung untuk melakukan perjalanan sendirian, sehingga jumlah penumpang adalah 1 orang perkendaraan yang merupakan orang yang mengendarai atau sopir dari kendaraan tersebut. Konsekwensinya adalah akan semakin banyak jumlah kendaraan di jalan. Occupation rate ini dapat dikurangi apabila jumlah penumpang adalah lebih dari 1.

\section{DAFTAR PUSTAKA}

BPPN 2006. Effort to minimize the petrol consumption in transportation sector (in Bahasa). Jakarta: Bappenas (National Planning Body) of Indonesian Republic.

DISHUB 2010. Rencana Induk Transportasi. In: PERHUBUNGAN, D. (ed.). Padang: Dinas Perhubungan Kota Padang.

SOEHODHO, S. 2007. Motorization in Indonesia and Its Impact to Traffic Accidents. IATSS Research, 31, 2733.

YALDI, G., APWIDDHAL, NUR, I. M. \& MOMON 2014. Local Traffic and Public Transport Portraits: A case study in padang City The 17th FSTPT International Symposium. Jember, Indonesia: FSTPT. 